\title{
Suhuai suckling piglet ionomic-metabolome responses to different dietary copper level in antibiotic free creep feed
}

Feng Zhang

Nanjing Agricultural University

Weijiang Zheng

Nanjing Agricultural University

Yongqiang Xue

Nanjing Agricultural University

Wen Yao ( $\nabla$ yaowen67jp@njau.edu.cn )

Nanjing Agricultural University https://orcid.org/0000-0002-3726-7716

\section{Research}

Keywords: Dietary copper, ionomic profiles, metabolome, suckling piglets, antibiotic free

Posted Date: July 8th, 2020

DOI: https://doi.org/10.21203/rs.3.rs-39362/v1

License: (9) This work is licensed under a Creative Commons Attribution 4.0 International License. Read Full License 


\section{Abstract}

Background: High levels of dietary copper may enhance co-selection in favor of antibiotic resistant bacteria and promote the spread of antibiotic resistance. This possibility necessitates further assessment of the safety and utility of supplementing feed with copper.

Methods: Eighteen Suhuai sows at second parity were divided into 3 experimental groups in which their 180 suckling piglets had access to antibiotic free creep feed with different levels of copper supplementation: low copper diet (LC, $6 \mathrm{mg} \cdot \mathrm{kg} \mathrm{-1}$ ), control diet (CON, $20 \mathrm{mg} \cdot \mathrm{kg} \mathrm{-1}$ ), and high copper diet (HC, $300 \mathrm{mg} \cdot \mathrm{kg}-1$ ), which was offered ad libitum from day 14 until weaning at day 40 . The growth performance, serum biochemical parameters, ionomic profiles (hair, serum, and feces), fecal significant metabolites of suckling piglets, and the correlations were analyzed.

Results: In HC group, the average daily gain (ADG) and average daily feed intake (ADFI) increased during d 14 to 28 ( $P<0.05)$, but ADG was decreased with extension of feeding time (d 29 to 40$)(P<0.01)$. Compared with the CON group, the tumor necrosis factor-a $(T N F-a)(P<0.05)$ was decreased while total antioxidant capacity $(\mathrm{T}-\mathrm{AOC})(\mathrm{P}<0.05)$ was increased in $\mathrm{HC}$ group. The hair $\mathrm{Na}(\mathrm{P}<0.01)$ and $\mathrm{K}(\mathrm{P}<$ $0.01)$ concentrations were increased in $\mathrm{HC}$ group than $\mathrm{CON}$ group; hair $\mathrm{Cu}(\mathrm{P}<0.01)$, fecal $\mathrm{Cu}(\mathrm{P}<0.01)$ increased in the HC group than LC group. The hair $\mathrm{Na}$ and $\mathrm{K}$ were negatively correlated with serum TNF-a and fecal inosine $(P<0.05)$, while positively correlated with serum insulin-like growth factors-1 (IGF-1) and T-AOC $(P<0.05)$; the hair Cu was negatively correlated with serum malondialdehyde (MDA), total bile acid (TBA) and fecal putrescine, glucose-6-phosphate, fumaric acid $(P<0.05)$; the fecal Cu was positively correlated with serum growth hormone $(P<0.05)$, negatively correlated with fecal methionine, pantothenic acid, and uracil $(P<0.05)$. Further metabolic pathway enrichment analysis showed that the hair $\mathrm{Cu}$ was negatively correlated with phenylalanine and tyrosine metabolism, and mitochondrial electron transport chain pathways; fecal Cu was negatively correlated with betaine metabolism, and pantothenate and CoA biosynthesis pathways.

Conclusions: Dietary $300 \mathrm{mg} \cdot \mathrm{kg}-1$ copper altered the ion balance and further affected the body's redox balance state and metabolic homeostasis, which adverse to the health of piglets; dietary $20 \mathrm{mg} \cdot \mathrm{kg}-1$ copper maintain ion homeostasis and suitable to meet the nutritional needs of suckling piglets than 6 $\mathrm{mg} \cdot \mathrm{kg}-1$ dietary copper.

\section{Background}

To prevent the selection for and the spread of antibiotic resistance, Sweden in 1986, then Denmark, the United Kingdom and many countries of the European Union banned the use of antibiotic agents as growth promoters in animal husbandry [1, 2]. As a consequence, many studies have concentrated on dietary alternatives to antibiotics, with considerable interest in supplementing diets with high levels of copper; however, using high levels of copper as an alternate to antibiotic growth promoters in animal production to control the emergence and propagation of antibiotic resistance has yielded limited success. 
Antibiotic resistance has not yet been eliminated in these European Union countries despite the introduced bans. Previous studies have shown that heavy metals used in animal farming may contribute to the spread of antibiotic resistance through co-selection [3], and Cu-induced spread of resistance to antibiotics relevant to veterinary and human medicine was discovered in 2002 [4], while many studies have proved that high levels of dietary copper may further enhance co-selection of antibiotic resistant bacteria $[1,5,6]$. Restrictions on trace mineral additives to livestock diets have already been implemented in Europe, but in China's swine industry, copper supplements are generally introduced at higher concentrations than required by the US National Research Council (NRC), which has suggested dietary $\mathrm{Cu}$ requirements for 5 to $25 \mathrm{~kg}$ nursery pigs and growing pigs of approximately 3 to $6 \mathrm{mg} \cdot \mathrm{kg}^{-1}$ [7]; these copper levels may be met by $\mathrm{Cu}$ in pig feed ingredients [8], or at higher levels (up to $16.5 \mathrm{mg} \cdot \mathrm{kg}^{-1}$ ) to compensate for dietary factors that could reduce absorption [9]. Dietary high level copper and their released ions, $\mathrm{Cu}^{2+}$, are believed to be one of the most important pollution-causing metals [10], while in China, use of antibiotics in swine production has only recently been banned [11], suggesting that it is time to be concerned about excess supplementation of feed with $\mathrm{Cu}$ in feed as well.

Copper is an essential trace element for pigs, and harmful to their health when dietary copper is deficient [12], and pharmacological $\mathrm{Cu}$ is routinely included to pig diets due to its pronounced promotion of growth [13-17]. Our previous studies have suggested that high levels of dietary copper ( 240 and $300 \mathrm{mg} \cdot \mathrm{kg}^{-1}$ ) affect the health of rats and suckling piglets by altering the composition of their intestinal microflora [18, 19], and we identified the need to properly evaluate whether excessive feed supplementation with $\mathrm{Cu}$ influences the absorption and utilization of other elements and metabolites, thus further impacting growth and health. Research on the growth-promotion effect of dietary copper has been mostly conducted in China and the United States, which did not ban the use of antibiotics from 2006 to 2014 [20]. In these studies of high levels of both copper and antibiotics in feed, it has been hard to distinguish efficiency effects came from copper supplements, because various antibiotics or antibacterial agents in combination with $\mathrm{CuSO}_{4}$ have demonstrated an additive performance effect in pigs [21].

Suhuai suckling piglets were used as our experiment model. Hybridization of Huai sows and Yorkshires began in 1958, and through decades of breeding Suhuai pigs were approved as a new breed in 2011 by China's national commission of animal genetic resources [19]. Copper supplementation in Suhuai piglets usually follows commercial standards despite the lack of breed-specific studies.

This study assumes a new perspective to evaluate the use of high levels of dietary copper, with the aim of investigating their effects on the ion balance and health status of Suhuai suckling piglets, to assess the safety and utility of high levels of copper in antibiotic free creep feed.

\section{Materials And Methods}

\section{Animal, Housing, Diets, and Sampling}


A total of 180 piglets (average initial weight approximately $1.11 \pm 0.18 \mathrm{~kg}$ ) from 18 multiparous Suhuai sows (second pregnancy) were assigned to 2 rooms ( 9 litters/room, 10 piglets per litter). In each litter, all piglets were selected based on similar body weight (BW), BW and sex were balanced among the piglets, and all piglets were individually weighed $72 \mathrm{~h}$ after farrowing. All 18 litters were randomly divided into three groups (6 litters/treatment): (i) low copper diet ( $\left(\mathrm{CC}, 6 \mathrm{mg} \cdot \mathrm{kg}^{-1}\right)$ containing no supplemental $\mathrm{Cu}$; (ii) control diet (CON, $\left.20 \mathrm{mg} \cdot \mathrm{kg}^{-1}\right)$; or (iii) high copper diet $\left(\mathrm{HC}, 300 \mathrm{mg} \cdot \mathrm{kg}^{-1}\right)$, with dietary copper supplementation by means of copper sulfate $\left(\mathrm{CuSO}_{4}\right)$. The piglets were trained to feed when 7 days old with a prefeeding period of 7 to 14 days, and the animal trials were conducted over 26 days (14-40 days), and the corn/soybean based diets were supplied throughout the experiment, meeting the nutritional requirements of the NRC [7] (see Additional file 1, Table S1). The piglets were housed together with their sow during the experimental period and with free access to creep feed and water, all piglets hindered to have access and eat the sow feed [19].

Each litter was monitored three times a day, and creep feeders were refilled as needed. Wet creep feed was removed, dried, and weighed and feeders were refilled approximately every $8 \mathrm{~h}$. Creep feed consumption were recorded daily. Individual pigs were weighed at $\mathrm{d} 14,28$, and 40 days post farrowing. Piglet BW and creep feed consumption were used to calculate ADG and ADFI. The diarrhea rate of piglets was recorded daily and calculated as follows: Diarrhea rete $(\%)=$ the number of pigs with diarrhea $x$ diarrhea days / ( the total number of pigs $\times$ experiment days) $\times 100 \%$, which the "number of pigs with diarrhea" was defined as the number of piglets with diarrhea was observed each day [22].

Before weaning, three litters were chosen within each treatment. Hair, feces and blood samples were harvested from four piglets/litter, selected based on average body weight (half male and female). Blood samples were stored in glass tubes with no anticoagulant and were allowed to clot at $4{ }^{\circ} \mathrm{C}$ before harvest of serum by centrifugation ( $15 \mathrm{~min}$ at $3500 \mathrm{rpm}$ ). Serum, hair and fecal samples were stored at $-80^{\circ} \mathrm{C}$ for subsequent analyses [18].

\section{Serum Biochemical Parameters Analysis}

Serum concentrations from piglets were detected for growth hormone (GH), IGF-1, leptin, and TNF-a using the enzyme-linked immunosorbent assay (ELISA) kits (Nanjing Jiancheng Bioengineering Institute, Nanjing, China). All examinations were performed according to the manufacturer's instructions [19].

\section{Element Analysis}

Thirteen elements including macro ( $\mathrm{Ca}, \mathrm{Mg}, \mathrm{Na}, \mathrm{K}, \mathrm{P})$, micro ( $\mathrm{Fe}, \mathrm{Cu}, \mathrm{Mn}, \mathrm{Zn}, \mathrm{Cr}$ ) and toxic ( $\mathrm{Pb}, \mathrm{Al}, \mathrm{Ni})$ elements were measured in hair, serum, and feces using inductively coupled plasma optical emission spectrometry (ICP-OES) (PerkinElmer, USA). Hair $(200 \mu \mathrm{g})$, serum $(1 \mathrm{~mL})$, and dried feces $(500 \mu \mathrm{g})$ were placed in a tube with $10 \mathrm{~mL}$ of a mixture of nitric acid (Guaranteed reagent, GR) and perchloric acid (GR) $(3: 1 \mathrm{v} / \mathrm{v})$. After digestion overnight, tubes were heated from $100{ }^{\circ} \mathrm{C}$ to $240{ }^{\circ} \mathrm{C}$ over approximately $3 \mathrm{~h}$, and 
the resulting digests brought to constant volume with double distilled deionized water [18, 23]. The standard liquid of $\mathrm{Ca}, \mathrm{Mg}, \mathrm{Na}, \mathrm{K}$, and $\mathrm{P}\left(1000 \mu \mathrm{g} \cdot \mathrm{mL}^{-1}\right)$ were mixed to prepare a $5 \mathrm{~mL}$ mixed standards with $0.5 \mathrm{~mol} \cdot \mathrm{L}^{-1} \mathrm{HNO}_{3}$. Take $0.5 \mathrm{~mL}$ mixed standard of $\mathrm{Fe}, \mathrm{Cu}, \mathrm{Mn}, \mathrm{Zn}$ and $\mathrm{Cr}\left(1000 \mu \mathrm{g} \cdot \mathrm{mL}^{-1}\right)$, constant volume to $5 \mathrm{~mL}$ secondary mother liquor $\left(100 \mu \mathrm{g} \cdot \mathrm{mL}^{-1}\right)$, then using secondary mother liquor prepare $10 \mathrm{~mL}$ standard with $0.5 \mathrm{~mol} \cdot \mathrm{L}^{-1} \mathrm{HNO}_{3}$. Take $0.5 \mathrm{~mL}$ mixed standard of $\mathrm{Pb}$, Al, and $\mathrm{Ni}\left(1000 \mu \mathrm{g} \cdot \mathrm{mL}^{-1}\right)$, constant volume 2 times and prepare $5 \mathrm{~mL}$ secondary mother liquor $\left(10 \mu \mathrm{g} \cdot \mathrm{mL}^{-1}\right)$, then prepare $10 \mathrm{~mL}$ standard with $0.5 \mathrm{~mol} \cdot \mathrm{L}^{-1} \mathrm{HNO}_{3}$. According to the instrument software settings, the determination of each standard of solution's absorbance value, each sample determination of repeated three times, get the element of standard curve, according to the standard curve of the conversion of each element content in the samples.

\section{Fecal metabolite profiles analysis}

The fecal samples preparation for gas chromatography-mass spectrometer analysis and data acquisition and processing were consistent with what we've already published (see Additional file 1) [19]. The fecal metabolites with variable important projection (VIP) value $>1.0$ and one-way analysis of variance (ANOVA) $P$ values $<0.05$ were considered as significant metabolites among the three dietary groups [19].

\section{Statistical analysis}

Growth performance and serum biochemical parameters as well as hair ionomic profiles were compared among the groups by means of a one-way ANOVA after any needed normal test processing and data conversion. For data found not to possess a normal distribution, the nonparametric Kruskal-Wallis test was utilized. Correlation analysis was conducted using a Karl-Pearson correlation test. Significant differences were declared when $P<0.05$. The statistical analysis was done using SPSS Statistics Version 22 (https://www.ibm.com/analytics/spss-statistics-software) [19].

\section{Results}

\section{Growth Performance}

During phase 1 (d 14 to 28$)$ the ADG $(P<0.05)$ and ADFI $(P<0.05)$ in the HC group increased, compared with the LC or CON groups (Table 1), and with extension of feeding time ADG $(P<0.01)$ was decreased in the HC group compared with the LC and CON groups ( 29 to 40). The diarrhea rate of the HC group was significantly decreased $(P<0.05)$ compared with LC groups for the entire experimental period. 
Table 1

Effects of dietary copper on the growth performance of suckling piglets (Mean $\pm S D$ )

\begin{tabular}{|c|c|c|c|c|c|}
\hline \multirow[t]{2}{*}{ Items } & \multicolumn{3}{|c|}{ Cu supplementation, $\mathrm{mg} \cdot \mathrm{kg}^{-1}$ diet } & \multirow[t]{2}{*}{ SEM } & \multirow[t]{2}{*}{$P$-value } \\
\hline & $\mathrm{LC}(6)$ & CON (20) & $\mathrm{HC}(300)$ & & \\
\hline \multicolumn{6}{|c|}{ Phase $1, \mathrm{~d} 14$ to 28} \\
\hline$A D G, g$ & $170.77 \pm 30.10^{b}$ & $183.28 \pm 34.81^{\mathrm{ab}}$ & $197.45 \pm 18.92^{\mathrm{a}}$ & 6.89 & $<0.05$ \\
\hline$A D F I, g$ & $49.77 \pm 4.23^{a b}$ & $45.50 \pm 5.50^{b}$ & $62.44 \pm 15.23^{a}$ & 2.76 & $<0.05$ \\
\hline $\mathrm{G}: \mathrm{F}$ & $3.47 \pm 0.76$ & $4.12 \pm 1.11$ & $3.29 \pm 0.77$ & 0.22 & 0.26 \\
\hline \multicolumn{6}{|c|}{ Phase 2, d 29 to 40} \\
\hline$A D G, g$ & $202.95 \pm 26.11^{\mathrm{a}}$ & $214.92 \pm 16.30^{\mathrm{a}}$ & $163.68 \pm 36.74^{b}$ & 8.11 & $<0.05$ \\
\hline ADFI, g & $120.06 \pm 16.06$ & $117.88 \pm 18.14$ & $118.21 \pm 21.46$ & 4.14 & 0.98 \\
\hline $\mathrm{G}: \mathrm{F}$ & $1.73 \pm 0.41$ & $1.86 \pm 0.29$ & $1.45 \pm 0.51$ & 0.10 & 0.26 \\
\hline \multicolumn{6}{|c|}{ Overall, d 14 to 40} \\
\hline$A D G, g$ & $185.92 \pm 25.98$ & $198.02 \pm 20.53$ & $183.36 \pm 13.28$ & 2.76 & 0.44 \\
\hline ADFI, g & $74.28 \pm 4.61$ & $72.92 \pm 9.03$ & $81.30 \pm 13.45$ & 2.33 & 0.31 \\
\hline $\mathrm{G}: \mathrm{F}$ & $2.51 \pm 0.39$ & $2.76 \pm 0.53$ & $2.31 \pm 0.45$ & 0.11 & 0.27 \\
\hline Diarrhea rate, \% & $8.74 \pm 3.99^{a}$ & $6.55 \pm 5.37^{a b}$ & $2.22 \pm 1.18^{b}$ & 1.09 & $<0.05$ \\
\hline
\end{tabular}

\section{Serum Biochemical Parameters}

Compared with other groups, serum growth hormone of the HC group $(P<0.05)$ increased, while albumin $(P<0.05)$ was significantly decreased (Table 2). Compared with the CON group, ALT $(P<0.05)$ and AST $(P<0.01)$ as well as MDA $(P=0.05)$ for the LC group increased, and T-AOC $(P<0.05)$ also increased in the HC group, while TNF-a $(P<0.05)$ decreased in HC group. Compared with the CON group, serum BUN $(P<$ $0.01)$ and SOD $(P=0.09)$ increased in the LC and HC groups. 
Table 2

Effects of dietary copper on serum biochemical parameters in suckling piglets (Mean $\pm S D$ )

Items

Cu supplementation, $\mathrm{mg} \cdot \mathrm{kg}^{-1}$ diet

SEM $P$-value

LC (6)

$\operatorname{CON}(20)$

$\mathrm{HC}(300)$

Growth related hormones

$\begin{array}{llllll}\text { Growth hormone, } \mathrm{ng} \cdot \mathrm{mL}^{-1} & 1.21 \pm 0.31^{\mathrm{b}} & 1.19 \pm 0.43^{\mathrm{b}} & 1.67 \pm 0.41^{\mathrm{a}} & 0.08 & <0.05\end{array}$

$\begin{array}{llllll}\text { IGF-1, U } \mathrm{mL}^{-1} & 9.52 \pm 1.93 & 9.68 \pm 2.23 & 10.95 \pm 2.07 & 0.38 & 0.26\end{array}$

$\begin{array}{llllll}\text { Leptin, } \mathrm{ng} \cdot \mathrm{mL}^{-1} & 5.87 \pm 0.71 & 5.79 \pm 1.11 & 5.26 \pm 1.59 & 0.21 & 0.46\end{array}$

Inflammatory cytokine

$\begin{array}{llllll}\text { TNF-a, ng. } \text { L }^{-1} & 70.43 \pm 13.96^{\mathrm{ab}} & 80.03 \pm 24.82^{\mathrm{a}} & 58.37 \pm 17.78^{\mathrm{b}} & 3.69 & <0.05\end{array}$

Oxidative, antioxidant enzymes

$\begin{array}{llllll}\text { T-AOC, } \mathrm{U} \cdot \mathrm{mL}^{-1} & 2.14 \pm 0.65^{\mathrm{ab}} & 1.64 \pm 0.43^{\mathrm{b}} & 2.33 \pm 0.76^{\mathrm{a}} & 0.12 & <0.05 \\ \text { MDA, nmol} \cdot \mathrm{mL}^{-1} & 3.46 \pm 0.77^{\mathrm{a}} & 2.83 \pm 0.53^{\mathrm{b}} & 3.01 \pm 0.46^{\mathrm{ab}} & 0.11 & 0.05 \\ \text { SOD, U. } \mathrm{mL}^{-1} & 142.93 \pm 14.00 & 149.94 \pm 7.47 & 138.51 \pm 13.63 & 2.20 & 0.09\end{array}$

Hepatic function

\begin{tabular}{llllll}
\hline ALT, $\mathrm{U} \cdot \mathrm{L}^{-1}$ & $11.47 \pm 4.38^{\mathrm{a}}$ & $7.59 \pm 2.00^{\mathrm{b}}$ & $8.55 \pm 3.17^{\mathrm{ab}}$ & 0.63 & $<0.05$ \\
\hline AST, $\mathrm{U} \cdot \mathrm{L}^{-1}$ & $9.17 \pm 2.28^{\mathrm{a}}$ & $6.02 \pm 1.73^{\mathrm{b}}$ & $7.06 \pm 2.08^{\mathrm{ab}}$ & 0.41 & $<0.01$ \\
\hline TBA, $\mu \mathrm{mol} \cdot \mathrm{gprot}^{-1}$ & $91.30 \pm 43.07^{\mathrm{a}}$ & $53.74 \pm 24.94^{\mathrm{b}}$ & $55.82 \pm 18.57^{\mathrm{b}}$ & 6.14 & $<0.05$ \\
\hline T-CHOL, $\mathrm{nmol} \cdot \mathrm{L}^{-1}$ & $3.27 \pm 0.59$ & $3.68 \pm 0.95$ & $3.06 \pm 0.60$ & 0.14 & 0.15 \\
\hline Albumin, $\mathrm{g} \cdot \mathrm{L}^{-1}$ & $27.23 \pm 4.18^{\mathrm{a}}$ & $27.01 \pm 3.41^{\mathrm{a}}$ & $23.83 \pm 2.16^{\mathrm{b}}$ & 0.62 & $<0.05$ \\
\hline Renal function & & & & \\
\hline BUN, mmol $\cdot \mathrm{L}^{-1}$ & $3.98 \pm 0.60^{\mathrm{b}}$ & $4.62 \pm 0.62^{\mathrm{a}}$ & $3.68 \pm 0.84^{\mathrm{b}}$ & 0.14 & $<0.01$ \\
\hline Creatinine, $\mu \mathrm{mol} \cdot \mathrm{L}^{-1}$ & $59.22 \pm 12.98$ & $70.36 \pm 14.57$ & $60.39 \pm 15.20$ & 2.58 & 0.14 \\
\hline BUN/Creatinine & $70.40 \pm 19.79$ & $67.82 \pm 14.77$ & $65.85 \pm 25.43$ & 3.44 & 0.88 \\
\hline a,b Values within a row without a common superscript letter are significantly different $(P<0.05)$.
\end{tabular}

Ionomic profiles 
In hair, $\mathrm{Mg}(P<0.05)$ and $\mathrm{Al}(P=0.07)$ in the CON group increased compared with the LC and HC groups. $\mathrm{Na}(P<0.01)$ concentration increased in the $\mathrm{HC}$ group compared with other groups. Compared with the CON group, $\mathrm{K}(P<0.01)$ in the $\mathrm{HC}$ group was increased, while $\mathrm{P}(P<0.05), \mathrm{Mn}(P<0.05)$ and $\mathrm{Fe}(P=0.07)$ decreased. $\mathrm{Cu}(P<0.01)$ concentration in the LC group decreased compared with the HC group (Figure 1a, $\mathrm{b}$ and $\mathrm{c})$. In serum, $\mathrm{Ca}(P=0.05)$ and $\mathrm{P}(P<0.05)$ concentrations in the $\mathrm{HC}$ group increased compared with the LC group, and $\mathrm{Mg}(P<0.05)$ increased in CON group (Figure 1d). In feces, $\mathrm{Cu}(P<0.01)$ concentration increased in the HC group compared with the LC group (Figure 1h).

\section{Fecal significant metabolites profiles}

Our previous analysis showed that a total of 47 significant fecal metabolites were identified among the three dietary group (see Additional file 1, Table S2) [19].The effects of dietary copper level on normalized relative abundance of fecal significant metabolites were shown in Figure 2. Compared with $\mathrm{HC}$ group, the relative abundance of leucine, proline, tyrosine, phenylalanine, methionine (Figure 2a), fructose-6phosphate, mannose-6-phosphate, glucose-6-phosphate (Figure 2b), and 2-hydroxyglutaric acid (Figure $2 \mathrm{c})$ were increased in $\mathrm{CON}$ group $(P<0.05)$. The relative abundance of remaining 23 significant metabolites in CON group were increased than other groups $(P<0.05)$.

\section{Changes in correlation patterns among elements in hair, serum and feces}

Correlation patterns among elements at different dietary copper levels are presented in Figure 3. In hair, the number of correlations in the macro-micro category (upper-left, Figure 3a, b and c) in the CON group was greater than for other groups. Compared with the $\mathrm{CON}$ group, the correlations of $\mathrm{Cu}=\mathrm{f}(\mathrm{Mg}), \mathrm{Mn}=$ $f(\mathrm{Na}, K)$, and $\mathrm{Zn}=f(K)$ were negligible in both the $L C$ and $H C$ groups. The correlations of $F e=f(M g), C u=$ $f(\mathrm{Na}, \mathrm{K}), \mathrm{Mn}=f(\mathrm{Na}, \mathrm{K}), \mathrm{Zn}=f(\mathrm{Na}, \mathrm{K})$, and $\mathrm{Zn}=f(\mathrm{Ca}, \mathrm{P})$ were negligible in the HC group. In the toxic-micro and toxic-macro categories (upper-right and bottom left, Figure $3 a, b$ and $c), N i=f(C r, C u)$ and $A l=f(N a, K)$ were negligible in both the $L C$ and $\mathrm{HC}$ groups compared with the $\mathrm{CON}$ group, while $\mathrm{Al}=\mathrm{f}(\mathrm{Cr})$ and $\mathrm{Pb}=\mathrm{f}(-$ $\mathrm{Cu},-\mathrm{Na}$ ) appeared in the $\mathrm{HC}$ group. In serum, in the macro-micro category (upper-left, Figure 3d, e and f), $\mathrm{Fe}=f(\mathrm{Ca}, \mathrm{Mg}, \mathrm{Na}, \mathrm{P}), \mathrm{Cu}=f(\mathrm{Ca}), \mathrm{Mn}=f(\mathrm{Ca}, \mathrm{Mg})$ and $\mathrm{Cr}=f(P)$ were negligible, while $\mathrm{Cu}=f(\mathrm{Na}, \mathrm{P})$ appeared in both the LC and HC groups. No significant positive correlations were observed between toxic and micro or macro elements in the CON group. In feces, the negative correlations of $\mathrm{Ca}$ and $\mathrm{P}$ with most micro and toxic elements were negligible, while the positive correlation of $\mathrm{Mg}$ and $\mathrm{K}$ were appeared when dietary copper levels increased from 20 to $300 \mathrm{mg} \cdot \mathrm{kg}^{-1}$.

\section{Correlation between ionomic profiles and serum biochemical parameters}

The correlation between ionomic profiles and serum biochemical parameters were presented in Figure 4 . Growth hormone was positively correlated with fecal $\mathrm{Cu}$ and $\mathrm{Zn}(P<0.05)$; serum TNF-a was negatively correlated with hair $\mathrm{Na}$ and $\mathrm{K}(P<0.05)$ and positively correlated with fecal $\mathrm{Cr}(P<0.05)$; serum MDA was negatively correlated with hair $\mathrm{Fe}, \mathrm{Cu}$, and $\mathrm{Mn}(P<0.05)$ and positively correlated with fecal $\mathrm{Fe}, \mathrm{Cr}$ and $\mathrm{Pb}$ $(P<0.05)$; serum T-AOC was positively correlated with hair $\mathrm{Na}$ and $\mathrm{K}(P<0.05)$ and negatively correlated with fecal $\mathrm{Mg}$, $\mathrm{P}$, and $\mathrm{Zn}(P<0.05)$; serum TBA was negatively correlated with hair and serum $\mathrm{Cu}$ and 
fecal $\mathrm{Na}(P<0.05)$ and positively correlated with hair $\mathrm{Pb}(P<0.05)$; serum albumin was positively correlated with fecal Fe $(P<0.05)$; serum BUN was negatively correlated with fecal $\mathrm{Cu}(P<0.05)$.

\section{Correlation between ionomic profiles and fecal significant metabolites}

The correlation between ionomic profiles and fecal significant metabolites were presented in Figure 5 . Hair $\mathrm{Na}$ and $\mathrm{K}$ were negatively correlated with inosine $(P<0.05)$; hair $\mathrm{Cu}$ was negatively correlated with putrescine, 2-aminobutyric acid, glucose-6-phosphate, mannose-6-phosphate, inosine, 2-methylbutanedioic acid, fumaric acid, and oxalic acid $(P<0.05)$; serum $\mathrm{Ca}, \mathrm{Mg}$, and $\mathrm{P}$ were negatively correlated with arginine, homoserine, ornithine, fructose-6-phosphate, 9-(Z)-Octadecenoic acid, 9,12-(Z,Z)Octadecadienoic acid, 2-hydroxyglutaric acid, and pantothenic acid $(P<0.05)$; fecal Cu was negatively correlated with methionine, malic acid, pantothenic acid, and uracil $(P<0.05)$.

The significant fecal metabolites correlated with ionomic profiles were used for further metabolic pathway enrichment analysis (Figure 6). The hair Cu was negatively correlated with nucleotide sugars metabolism, starch and sucrose metabolism, aspartate metabolism, phenylalanine and tyrosine metabolism, and mitochondrial electron transport chain pathways; serum $\mathrm{Ca}, \mathrm{Mg}$, and $\mathrm{P}$ were negatively correlated with Urea cycle, arginine and proline metabolism, and a-linolenic acid and linoleic acid metabolism pathways; fecal Cu was negatively correlated with $\beta$-alanine metabolism, betaine metabolism, malate-aspartate shuttle, and pantothenate and CoA biosynthesis pathways.

\section{Discussion}

Copper plays an important role in pigs for the synthesis of hemoglobin and activation of several oxidative enzymes necessary for normal metabolism [15]. Previous studies have shown that higher nutritional levels of $\mathrm{Cu}\left(\mathrm{as} \mathrm{CuSO}_{4}\right)$ at concentrations of 100 to $250 \mathrm{mg} \cdot \mathrm{kg}^{-1}$ improved growth performance in young pigs [24-26]. The National Research Council (NRC) suggests that the dietary Cu requirement for 5 to $25 \mathrm{~kg}$ nursery pigs and growing pigs is approximately 3 to $6 \mathrm{mg}^{\circ} \mathrm{kg}^{-1}$ [7], suggesting that Cu requirements may be met by Cu present in feed ingredients when piglets are fed a corn-soybean base diet [8]. In our study, LC $\left(6 \mathrm{mg} \cdot \mathrm{kg}^{-1} \mathrm{Cu}\right)$ seems unable to meet the nutritional needs of suckling piglets when antibiotics are withdrawn from creep feed because the G:F value decreased compared with the CON group (20 $\mathrm{mg} \cdot \mathrm{kg}^{-1} \mathrm{Cu}$ ), and the diarrhea rate significantly increased compared with the $\mathrm{HC}$ group $\left(300 \mathrm{mg} \cdot \mathrm{kg}^{-1} \mathrm{Cu}\right.$ ) group. We also observed that $300 \mathrm{mg} \cdot \mathrm{kg}^{-1}$ of dietary Cu enhanced ADG and ADFI during days 14 to 28 , but that $A D G$ and the G:F value decreased during days 29 to 40 . Taken together with the lack of a significant growth response to high levels of Cu over the entire experimental period, these results suggest that high levels of dietary copper can promote short term growth. It has been believed that the growthpromoting effects of copper are related to the $\mathrm{GH}$ axis and might be generated by the stimulation of $\mathrm{GH}$ secretions [27]. Our study observed that serum GH increased in the $\mathrm{HC}$ group, similar to the results of a previous study which showed that high copper levels (100 to $300 \mathrm{mg} \cdot \mathrm{kg}^{-1}$ ) can increase serum GH concentrations in weaning pigs [28]. However, high levels of copper did not affect the serum IGF-1 in our 
study, unlike Wang's previous study, which found that dietary copper $\left(250 \mathrm{mg} \cdot \mathrm{kg}^{-1}, \mathrm{CuSO}_{4}\right)$ increased serum IGF-1 concentrations on days 20 and 40 for weanling pigs, with the rise in serum IGF-1 partly due to increased feed intake [29]. In our study ADFI was no longer significantly increased in the HC group during days 29 to 40 . When piglets were fed a $20 \mathrm{mg} \cdot \mathrm{kg}^{-1} \mathrm{Cu}$ diet, they tended to gain more and eat less among the three groups across the entire experimental period, while their diarrhea rate was within an acceptable range. Twenty $\mathrm{mg} \cdot \mathrm{kg}^{-1}$ of $\mathrm{Cu}$ in an antibiotic free diet thus would be adequate to meet requirements of suckling piglets.

To investigate the effects of high levels of dietary copper on the health of piglets, serum biochemical parameters were further analyzed. In the HC group, TNF-a concentrations decreased. This result suggested that high levels of copper may have a potential anti-inflammatory effect when antibiotics are withdrawn from the diet. In the current study, serum T-AOC concentration increased in the HC group, reflecting the status of antioxidants in the serum [30], suggesting that high levels of copper in the diet had an obvious effect on the antioxidative status of suckling piglets. In our study, compared with other groups, MDA decreased and SOD tended to increase in the CON group, suggesting that dietary concentrations of $20 \mathrm{mg} \cdot \mathrm{kg}^{-1} \mathrm{Cu}$ enhance the ability to resist oxidative stress in piglets. However, SOD tended to decrease in the HC group, because high levels of copper may weaken the activation of SOD, which was in agreement with our previous study that found the mRNA levels of Ccs and Sod1 genes were reduced by high levels of dietary copper $\left(240 \mathrm{mg} \cdot \mathrm{kg}^{-1}\right)$ in the liver of SD rats (see Additional file 1, Figure S1). Our results also suggested that liver dysfunction might occurred in piglets in the LC and HC groups because of observed elevations in ALT, AST and bile acid levels in serum, considered valuable biomarkers for the diagnosis of hepatic disease [31-33]. Kidney function seems to be maintained in all piglets as evidenced by the fact that BUN/creatinine levels were not affected by the level dietary copper, which is considered a marker for identifying acute kidney injury (AKI) [34].

Viewing human hair as an excretory system for trace metals, and considering that concentrations of these elements in hair are reported to be correlated with the diagnosis of various diseases [35], hair mineral analysis has become an interesting diagnostic tool in assessment of health and nutritional status [36,37]. In our study, of the 13 elements tested, concentrations of eight elements in hair were affected by levels of dietary copper, with hair $\mathrm{Na}, \mathrm{K}$, and $\mathrm{Cu}$ increasing in the $\mathrm{HC}$ group, suggesting that $\mathrm{Na}-\mathrm{K}$ balance changes and reabsorption decreased. Concentrations in hair $\mathrm{Fe}, \mathrm{Mn}$ and $\mathrm{Al}$ increased in the CON group more than in the $\mathrm{HC}$ group, and strong positive correlations between Fe-Al $(r=0.851)$ and $\mathrm{Mn}$ Al ( $r=0.808)$ were observed (see Additional file 1, Table S3). These elements share the same uptake mechanism (transferrin), and $\mathrm{Fe}, \mathrm{Mn}$ and $\mathrm{Al}$ are related to inflammation in humans and animals [38], corroborated by an observed increase in TNF-a in the CON group. Noteworthy changes were seen in the correlation pattern between macro and micro or toxic elements with increased copper levels in the diet (Fig. 2). The number of positive correlations between macro-micro elements in hair and serum increased in the CON group compared with other groups (Fig. $2 \mathrm{~b}$ and e); further, the absorption, utilization and excretion of many trace elements in animals are greatly affected by other trace elements [39], so these results suggest that dietary $20 \mathrm{mg} \cdot \mathrm{kg}^{-1} \mathrm{Cu}$ can maintain homeostasis in piglets due to maintenance of 
the interactions between macro and micro elements [12]. Correlations between hair macro $(\mathrm{Na}, \mathrm{K})$ and micro (Cu, Mn, Zn) elements appear in the HC group (Fig. 2c), and as is well known, trace elements such as $\mathrm{Cu}, \mathrm{Zn}$ and $\mathrm{Mn}$ are essential for normal growth, disease resistance, production and reproduction in farm animals [12], suggesting that a dietary dose of $300 \mathrm{mg} \cdot \mathrm{kg}^{-1} \mathrm{Cu}$ changed the balance of Na-K and affected the absorption and utilization of $\mathrm{Cu}, \mathrm{Mn}$, and $\mathrm{Zn}$. We also observed that a negative correlation of toxic ( $\mathrm{Pb}$ and $\mathrm{Al}$ ) elements appeared in the $\mathrm{HC}$ group. These changes could reflect imbalance or adverse status in these elements [38], and marginal or severe element imbalances can be considered risk factors for several diseases [40]. These results suggest that a dietary dose of $300 \mathrm{mg} \cdot \mathrm{kg}^{-1}$ Cu might have adverse effects on the health of suckling piglets.

To understand the relationship between the ion balance and health status of suckling piglets, correlations between ionomic profiles and serum biochemical parameters were analyzed. Hair $\mathrm{Na}$ and $\mathrm{K}$ were positively correlated with IGF-1 and T-AOC, and negatively correlated with TNF-a, these results suggested that changes in Na-K balance induced by $300 \mathrm{mg} \cdot \mathrm{kg}^{-1}$ of dietary Cu was related to the inflammatory response and antioxidant capacity. The concentrations of $\mathrm{Fe}$ in hair, serum, and feces were positively correlated with MDA, ALT, and albumin, a relationship between Fe concentrations and hepatic function has been reported [41], and $300 \mathrm{mg} \cdot \mathrm{kg}^{-1}$ of dietary Cu may affect the absorption of Fe and further damage the hepatic function, inducing oxidative stress in suckling piglets. Concentrations of $\mathrm{Cu}$ in hair, serum, and feces were negatively correlated with MDA, TBA, and BUN, suggesting that changes in $\mathrm{Cu}$ induced by $300 \mathrm{mg} \cdot \mathrm{kg}^{-1}$ of dietary Cu affects the hepatic function and causes oxidative damage [42]. Dietary $\mathrm{Cu}$ at a concentration of $300 \mathrm{mg} \cdot \mathrm{kg}^{-1}$ increased growth hormone in suckling piglets was demonstrated by the correlation between fecal $\mathrm{Cu}$ and growth hormone. The concentrations of $\mathrm{Zn}$ in hair and feces were positively correlated with MDA, T-AOC, and creatinine, since $\mathrm{Zn}$ has the function of stabilizing cell membrane structure and protecting free radicals from oxidative damage [43, 44], and participates in the regulation of liver function and urea production. In general, dietary high level copper affected the ionomic profiles which in turn adversely affects the health of suckling piglets.

As we know, fecal metabolites reflect the final status of animal digestion, absorption, and metabolism of feed nutrients [19]. Our previous analysis of fecal significant metabolites showed that the capacity of dietary monosaccharide and protein absorption decreased, and the level of organic acids were increased in suckling piglets those fed with $6 \mathrm{mg} \cdot \mathrm{kg}^{-1} \mathrm{Cu}$ diet (Fig. 2), these suggest that $6 \mathrm{mg} \cdot \mathrm{kg}^{-1} \mathrm{Cu}$ supplementation has an adverse effect on the health of piglets when antibiotic withdrawn from the feed [19]. In this study, we are concerned about changes in the composition of elements in hair, which reflect the body's metabolism changes [40], the correlation and enrichment analysis showed that the $\mathrm{Na}$ and $\mathrm{K}$ in hair which significantly affected by dietary copper were negatively correlated with fecal inosine (Fig. 5), consistent with the result that hair $\mathrm{Na}$ and $\mathrm{K}$ were negatively correlated with serum TNF-a (Fig. 4), due to the inosine is a purine metabolite and has a systemic anti-inflammatory effect [45]. The hair Cu was significantly increased in $\mathrm{HC}$ group than LC group, and negatively correlated with phenylalanine and tyrosine metabolism pathways (Fig. 6), dopamine $\beta$-hydroxylase (DBH) and phenylalanine hydrolase are two key enzymes in these pathways which its cofactor is copper $[46,47]$. The hair Cu was negatively 
correlated with mitochondrial electron transport chain pathway (Fig. 6), various enzymes in this pathway use copper as a cofactor, such as cytochrome $c$ oxidase and nicotinamide adenine dinucleotide (NADH) dehydrogenase [46-48]. The activity of the electron transport chain is related to the generation of reactive oxygen species (ROS) and the body's redox state $[49,50]$, in this study, dietary $300 \mathrm{mg} \cdot \mathrm{kg}^{-1}$ Cu enhanced mitochondrial electron transport chain pathway which promoted the formation of ROS and affecting the redox status of piglets, these verified by the results of negative correlation between hair $\mathrm{Cu}$ and serum MDA (Fig. 4).

The fecal Cu content mainly comes from the accumulation of unabsorbed copper in the diet. In our study, fecal Cu was negatively correlated with betaine metabolism pathway, betaine is an important methyl donor in the process of homocysteine synthesis of methionine and an important intermediate in the process of energy metabolism [51, 52], the process by which betaine provides methyl groups is mainly catalyzed by betaine homocysteine transferase (BHMT), a cytoplasmic enzyme that relies on zinc activation [53], due to the antagonism between copper and zinc [12], suggested that dietary high level copper hinder the absorption of zinc to a certain extent, and inhibit the activity of BHMT as well as the function of betaine methyl donor. In the process of betaine producing methionine, homocysteine is also a substrate for the enzyme action of BHMT, when the activity of BHMT decreases, the level of homocysteine in the blood rises, which has a certain relationship with vascular disease, thrombosis and renal dysfunction $[54,55]$, these suggested that $300 \mathrm{mg} \cdot \mathrm{kg}^{-1} \mathrm{Cu}$ inhibited the methyl supply capacity of betaine and further affected protein biosynthesis and the health of suckling piglets. Our previous study found that the level of pantothenic acid was decreased in HC group [19], the enrichment analysis in this study showed that the fecal Cu was negatively correlated with pantothenate and coenzyme A (CoA) biosynthesis pathway, pantothenic acid plays an important role in the process of decomposing carbohydrates, fatty acids and amino acids to produce energy [56]. The results of this experiment showed that dietary high level copper affected the digestion and absorption of diets by piglets, which in turn affected the biosynthesis of pantothenic acid and CoA, further affected carbohydrate, fat, amino acid, and energy metabolism of suckling piglets, leading to changes in metabolic homeostasis.

\section{Conclusions}

In conclusion, $300 \mathrm{mg} \cdot \mathrm{kg}^{-1}$ of dietary copper promoted growth in the short term but exhibited a lack of a significant growth over the entire experimental period, and altered the ion balance of $\mathrm{Na}, \mathrm{K}$ and $\mathrm{Fe}, \mathrm{Cu}, \mathrm{Zn}$, which may damage the body's redox balance state and hepatic function of piglets, further affected the metabolism of carbohydrate, fat, and amino acid. Six $\mathrm{mg} \cdot \mathrm{kg}^{-1}$ of dietary $\mathrm{Cu}$ seems unable to meet the nutritional needs of suckling piglets. Twenty $\mathrm{mg} \cdot \mathrm{kg}^{-1}$ of dietary Cu can effectively improve antioxidant capacity, protect tissues from oxidative damage, and maintain homeostasis due to preservation of the interactions between macro and micro elements, and it seems suitable for meeting the needs and maintaining the health of suckling piglets. These analyses and results may help us understand the effects of micronutrient intake on animal and human health. 


\section{List Of Abbreviations}

$A D F I$, average daily feed intake; $A D G$, average daily gain; ALT, alanine aminotransferase; AST, aspartate transaminase; BUN, blood urea nitrogen; CoA, coenzyme A; DBH, dopamine $\beta$-hydroxylase; $\mathrm{GH}$, growth hormone; GR, Guaranteed reagent. IGF-1, insulin-like growth factors-1; MDA, malondialdehyde; NADH, nicotinamide adenine dinucleotide; ROS, reactive oxygen species; SEM, standard error of mean; SOD, superoxide dismutase; T-AOC, total antioxidant capacity; TBA, total bile acid; T-CHOL, total cholesterol; TNF-a, tumor necrosis factor-a.

\section{Declarations}

\section{Ethics approval}

This animal experimental protocol was implemented under the supervision of the Chinese Guidelines for Animal Welfare and Experimental Protocol and were approved by the Institutional Animal Care and Use Committee of Nanjing Agricultural University, China (NJAU-CAST-2015-098).

\section{Consent for publication}

Not applicable.

\section{Availability of data and materials}

All data generated or analyzed during this study are available from the corresponding author on reasonable request.

\section{Competing interests}

The authors declare that they have no competing interests.

\section{Funding}

This research was supported by the National Natural Science Foundation of China (NO. 31372321) and the earmarked fund for Jiangsu Modern Agricultural (Swine) Industry Technology System (SXGC[2019]430).

\section{Authors' contributions}

Wen Yao, Feng Zhang and Weijiang Zheng designed and supervised the experiments. Feng Zhang and Yongqiang Xue conducted the experiments. Feng Zhang and Yongqiang Xue performed the data measurements and statistical data analysis. Wen Yao and Feng Zhang wrote and revised the manuscript. All authors have read and approved the final manuscript.

\section{Acknowledgments}


We gratefully acknowledge the help of the farm staff of the Huaiyin breeding farm and of their technicians during sample collection and preparation. Dr. Zhang would especially thankful to his parents and wife Xiaodan Liu for their support and love.

\section{References}

1. Seiler C, Berendonk TU. Heavy metal driven co-selection of antibiotic resistance in soil and water bodies impacted by agriculture and aquaculture. Front Microbiol. 2012;3:399. doi:http://dx.doi.org/10.3389/fmicb.2012.00399.

2. Cogliani C, Goossens H, Greko C. Restricting Antimicrobial Use in Food Animals: Lessons from Europe. Microbe Magazine. 2011;6(6):274-9. doi:http://dx.doi.org/10.1128/microbe.6.274.1.

3. Baker-Austin C, Wright MS, Stepanauskas R, McArthur JV. Co-selection of antibiotic and metal resistance. Trends Microbiol. 2006;14(4):176-82. doi:http://dx.doi.org/10.1016/j.tim.2006.02.006.

4. Hasman $\mathrm{H}$, Aarestrup FM. tcrB, a gene conferring transferable copper resistance in Enterococcus faecium: occurrence, transferability, and linkage to macrolide and glycopeptide resistance. Antimicrob Agents Chemother. 2002;46(5):1410-6. doi:http://dx.doi.org/10.1128/aac.46.5.14101416.2002.

5. Brown NL, Rouch DA, Lee BT. Copper resistance determinants in bacteria. Plasmid. 1992;27(1):4151. doi:http://dx.doi.org/10.1016/0147-619x(92)90005-u.

6. Holzel CS, Muller C, Harms KS, Mikolajewski S, Schafer S, Schwaiger K, et al. Heavy metals in liquid pig manure in light of bacterial antimicrobial resistance. Environ Res. 2012;113(2012):21-7. doi:http://dx.doi.org/10.1016/j.envres.2012.01.002.

7. NRC. Nutrient requirements of swine. 11th ed. Washington, DC: The national academies press; 2012.

8. Bikker P, Jongbloed AW, van Baal J. Dose-dependent effects of copper supplementation of nursery diets on growth performance and fecal consistency in weaned pigs. J Anim Sci. 2016;94(3):181-6. doi:https://doi.org/10.2527/jas2015-9874.

9. Zou X, Weng M, Ji X, Guo R, Zheng W, Yao W. Comparison of antibiotic resistance and copper tolerance of Enterococcus spp. and Lactobacillus spp. isolated from piglets before and after weaning. J Microbiol. 2017;55(9):703-10. doi:https://doi.org/10.1007/s12275-017-6241-x.

10. Zhao G, Zhang T, Sun H, Liu JX. Copper nanoparticles induce zebrafish intestinal defects via endoplasmic reticulum and oxidative stress. Metallomics. 2020;12(1):12-22. doi:https://doi.org/10.1039/c9mt00210c.

11. Dyar OJ, Zhang T, Peng Y, Sun M, Sun C, Yin J, et al. Knowledge, attitudes and practices relating to antibiotic use and antibiotic resistance among backyard pig farmers in rural Shandong province, China. Prev Vet Med. 2020;175:104858. doi:https://doi.org/10.1016/j.prevetmed.2019.104858.

12. Goff JP. Minerals. In: Reece WO, editor. Dukes' physiology of domestic animals. 12th ed. Minerals. Ithaca and London: Cornell University Press; 2004. p. 575 - 99. 
13. Zhou W, Kornegay ET, van Laar H, Swinkels JW, Wong EA, Lindemann MD. The role of feed consumption and feed efficiency in copper-stimulated growth. J Anim Sci. 1994;72(9):2385-94. doi:http://dx.doi.org/10.2527/1994.7292385x.

14. Lu L, Wang RL, Zhang ZJ, Steward FA, Luo X, Liu B. Effect of dietary supplementation with copper sulfate or tribasic copper chloride on the growth performance, liver copper concentrations of broilers fed in floor pens, and stabilities of vitamin E and phytase in feeds. Biol Trace Elem Res. 2010;138(13):181-9. doi:http://dx.doi.org/10.1007/s12011-010-8623-3.

15. Ma YL, Zanton GI, Zhao J, Wedekind K, Escobar J, Vazquez-Anon M. Multitrial analysis of the effects of copper level and source on performance in nursery pigs. J Anim Sci. 2015;93(2):606-14. doi:https://doi.org/10.2527/jas.2014-7796.

16. Villagomez-Estrada S, Perez JF, Darwich L, Vidal A, van Kuijk S, Melo-Duran D, et al. Effects of copper and zinc sources and inclusion levels of copper on weanling pig performance and intestinal microbiota. J Anim Sci. 2020;98(5). doi:https://doi.org/10.1093/jas/skaa117.

17. Lin G, Guo Y, Liu B, Wang R, Su X, Yu D, et al. Optimal dietary copper requirements and relative bioavailability for weanling pigs fed either copper proteinate or tribasic copper chloride. J Anim Sci Biotechnol. 2020;11:54. doi:https://doi.org/10.1186/s40104-020-00457-y.

18. Zhang F, Zheng W, Guo R, Yao W. Effect of dietary copper level on the gut microbiota and its correlation with serum inflammatory cytokines in Sprague-Dawley rats. J Microbiol. 2017;55(9):694702. doi:https://doi.org/10.1007/s12275-017-6627-9.

19. Zhang F, Zheng W, Xue Y, Yao W. Suhuai suckling piglet hindgut microbiome-metabolome responses to different dietary copper levels. Appl Microbiol Biotechnol. 2019;103(2):853-68. doi:https://doi.org/10.1007/s00253-018-9533-0.

20. Kuehn BM. FDA moves to curb antibiotic use in livestock. JAMA. 2014;311(4):347-8. doi:http://dx.doi.org/10.1001/jama.2013.285704.

21. Carlson MS, Hill GM, Link JE. Early- and traditionally weaned nursery pigs benefit from phase-feeding pharmacological concentrations of zinc oxide: effect on metallothionein and mineral concentrations. J Anim Sci. 1999;77(5):1199-207. doi:http://dx.doi.org/10.2527/1999.7751199x.

22. Yin L, Li J, Wang H, Yi Z, Wang L, Zhang S, et al. Effects of vitamin B6 on the growth performance, intestinal morphology, and gene expression in weaned piglets that are fed a low-protein diet1. J Anim Sci. 2020;98(2). doi:https://doi.org/10.1093/jas/skaa022.

23. Lin Z-m, Ning H-f, Bi J-g, Qiao J-f, Liu Z-h, Li G-h, et al. Effects of Nitrogen Fertilization and Genotype on Rice Grain Macronutrients and Micronutrients. Rice Sci. 2014;21(4):233-42. doi:http://dx.doi.org/10.1016/s1672-6308(13)60178-x.

24. Cromwell GL, Lindemann MD, Monegue HJ, Hall DD, Orr DE Jr. Tribasic copper chloride and copper sulfate as copper sources for weanling pigs. J Anim Sci. 1998;76(1):118-23. doi:http://dx.doi.org/10.2527/1998.761118x.

25. Armstrong TA, Cook DR, Ward MM, Williams CM, Spears JW. Effect of dietary copper source (cupric citrate and cupric sulfate) and concentration on growth performance and fecal copper excretion in 
weanling pigs. J Anim Sci. 2004;82(4):1234-40. doi:http://dx.doi.org/10.2527/2004.8241234x.

26. Fry RS, Ashwell MS, Lloyd KE, O'Nan AT, Flowers WL, Stewart KR, et al. Amount and source of dietary copper affects small intestine morphology, duodenal lipid peroxidation, hepatic oxidative stress, and mRNA expression of hepatic copper regulatory proteins in weanling pigs. J Anim Sci. 2012;90(9):3112-9. doi:http://dx.doi.org/10.2527/jas.2011-4403.

27. Yang W, Wang J, Liu L, Zhu X, Wang X, Liu Z, et al. Effect of high dietary copper on somatostatin and growth hormone-releasing hormone levels in the hypothalami of growing pigs. Biol Trace Elem Res. 2011;143(2):893-900. doi:http://dx.doi.org/10.1007/s12011-010-8904-x.

28. Wang J, Zhu X, Guo Y, Wang Z, Zhao B, Yin Y, et al. Influence of Dietary Copper on Serum GrowthRelated Hormone Levels and Growth Performance of Weanling Pigs. Biol Trace Elem Res. 2016;172(1):134-9. doi:https://doi.org/10.1007/s12011-015-0574-2.

29. Carlson D, Poulsen HD, Vestergaard M. Additional dietary zinc for weaning piglets is associated with elevated concentrations of serum IGF-I. J Anim Physiol Anim Nutr (Berl). 2004;88(9-10):332-9. doi:http://dx.doi.org/10.1111/j.1439-0396.2004.00488.x.

30. Zhao CY, Tan SX, Xiao XY, Qiu XS, Pan JQ, Tang ZX. Effects of dietary zinc oxide nanoparticles on growth performance and antioxidative status in broilers. Biol Trace Elem Res. 2014;160(3):361-7. doi:http://dx.doi.org/10.1007/s12011-014-0052-2.

31. Chang YY, Chou CH, Chiu CH, Yang KT, Lin YL, Weng WL, et al. Preventive effects of taurine on development of hepatic steatosis induced by a high-fat/cholesterol dietary habit. J Agric Food Chem. 2011;59(1):450-7. doi:http://dx.doi.org/10.1021/jf103167u.

32. Masubuchi N, Nishiya T, Imaoka M, Mizumaki K, Okazaki O. Promising toxicological biomarkers for the diagnosis of liver injury types: Bile acid metabolic profiles and oxidative stress marker as screening tools in drug development. Chem Biol Interact. 2016;255(2016):74-82. doi:https://doi.org/10.1016/j.cbi.2015.09.012.

33. Fanali G, di Masi A, Trezza V, Marino M, Fasano M, Ascenzi P. Human serum albumin: from bench to bedside. Mol Aspects Med. 2012;33(3):209-90. doi:http://dx.doi.org/10.1016/j.mam.2011.12.002.

34. Takaya Y, Yoshihara F, Yokoyama H, Kanzaki H, Kitakaze M, Goto Y, et al. Risk Stratification of Acute Kidney Injury Using the Blood Urea Nitrogen/Creatinine Ratio in Patients With Acute Decompensated Heart Failure. Circ J. 2015;79(7):1520-5. doi:https://doi.org/10.1253/circj.CJ-14-1360.

35. Wang XO, Zhuang ZX, Zhu E, Yang CL, Wan T, Yu LJ. Multielement ICP-AES Analysis of Hair Samples and a Chemometrics Study for Cancer Diagnosis. Microchem J. 1995;51(1-2):5-14. doi:http://dx.doi.org/10.1006/mchj.1995.1004.

36. Li Y, Yang L, Wang W, Li H, Lv J, Zou X. Trace element concentrations in hair of healthy Chinese centenarians. Sci Total Environ. 2011;409(8):1385-90. doi:http://dx.doi.org/10.1016/j.scitotenv.2011.01.017.

37. Apostoli P. Elements in environmental and occupational medicine. J Chromatogr B Analyt Technol Biomed Life Sci. 2002;778(1-2):63-97. doi:http://dx.doi.org/10.1016/s0378-4347(01)00442-x. 
38. So KM, Lee Y, Bok JD, Kim EB, Chung MI. Analysis of lonomic Profiles of Canine Hairs Exposed to Lipopolysaccharide (LPS)-Induced Stress. Biol Trace Elem Res. 2016;172(2):364-71. doi:https://doi.org/10.1007/s12011-015-0611-1.

39. Patra RC, Swarup D, Sharma MC, Naresh R. Trace mineral profile in blood and hair from cattle environmentally exposed to lead and cadmium around different industrial units. J Vet Med A Physiol Pathol Clin Med. 2006;53(10):511-7. doi:http://dx.doi.org/10.1111/j.1439-0442.2006.00868.x.

40. Kosanovic M, Jokanovic M. Quantitative analysis of toxic and essential elements in human hair. Clinical validity of results. Environ Monit Assess. 2011;174(1-4):635-43. doi:http://dx.doi.org/10.1007/s10661-010-1484-6.

41. Bassett SE, Di Bisceglie AM, Bacon BR, Sharp RM, Govindarajan S, Hubbard GB, et al. Effects of iron loading on pathogenicity in hepatitis C virus-infected chimpanzees. Hepatology. 1999;29(6):188492. doi:http://dx.doi.org/10.1002/hep.510290623.

42. Gaetke LM, Chow CK. Copper toxicity, oxidative stress, and antioxidant nutrients. Toxicology. 2003;189(1-2):147-63. doi:http://dx.doi.org/10.1016/s0300-483x(03)00159-8.

43. Kolachi NF, Kazi TG, Afridi HI, Kazi NG, Khan S. Investigation of essential trace and toxic elements in biological samples (blood, serum and scalp hair) of liver cirrhotic/cancer female patients before and after mineral supplementation. Clin Nutr. 2012;31(6):967-73. doi:http://dx.doi.org/10.1016/j.clnu.2012.04.015.

44. Larson MR. Social desirability and self-reported weight and height. Int J Obes Relat Metab Disord. 2000;24(5):663-5. doi:http://dx.doi.org/10.1038/sj.ijo.0801233.

45. Ali-Sisto T, Tolmunen T, Toffol E, Viinamaki H, Mantyselka P, Valkonen-Korhonen M, et al. Purine metabolism is dysregulated in patients with major depressive disorder. Psychoneuroendocrino. 2016;70:25-32. doi:https://doi.org/10.1016/j.psyneuen.2016.04.017.

46. Kim BE, Nevitt T, Thiele DJ. Mechanisms for copper acquisition, distribution and regulation. Nat Chem Biol. 2008;4(3):176-85. doi:http://dx.doi.org/10.1038/nchembio.72.

47. Festa RA, Thiele DJ. Copper: an essential metal in biology. Curr Biol. 2011;21(21):R877-83. doi:http://dx.doi.org/10.1016/j.cub.2011.09.040.

48. Birsoy K, Wang T, Chen WW, Freinkman E, Abu-Remaileh M, Sabatini DM. An essential role of the mitochondrial electron transport chain in cell proliferation is to enable aspartate synthesis. Cell. 2015;162(3):540-51. doi:http://dx.doi.org/10.1016/j.cell.2015.07.016.

49. Bell EL, Klimova TA, Eisenbart J, Moraes CT, Murphy MP, Budinger GRS, et al. The Q(o) site of the mitochondrial complex III is required for the transduction of hypoxic signaling via reactive oxygen species production. J Cell Biol. 2007;177(6):1029-36. doi: http://www.jcb.org/cgi/doi/10.1083/jcb.200609074.

50. Di Lisa F, Ziegler M. Pathophysiological relevance of mitochondria in NAD(+) metabolism. Febs Lett. 2001;492(1-2):4-8. doi:http://dx.doi.org/10.1016/s0014-5793(01)02198-6.

51. Deminice R, da Silva RP, Lamarre SG, Kelly KB, Jacobs RL, Brosnan ME, et al. Betaine supplementation prevents fatty liver induced by a high-fat diet: effects on one-carbon metabolism. 
Amino Acids. 2015;47(4):839-46. doi:https://doi.org/10.1007/s00726-014-1913-x.

52. Zou H, Chen N, Shi M, Xian M, Song Y, Liu J. The metabolism and biotechnological application of betaine in microorganism. Appl Microbiol Biotechnol. 2016;100(9):3865-76. doi:https://doi.org/10.1007/s00253-016-7462-3.

53. Teng YW, Mehedint MG, Garrow TA, Zeisel SH. Deletion of betaine-homocysteine S-methyltransferase in mice perturbs choline and 1-carbon metabolism, resulting in fatty liver and hepatocellular carcinomas. J Biol Chem. 2011;286(42):36258-67. doi:http://dx.doi.org/10.1074/jbc.M111.265348.

54. Ganu R, Garrow T, Koutmos M, Rund L, Schook LB. Splicing variants of the porcine betainehomocysteine S-methyltransferase gene: implications for mammalian metabolism. Gene. 2013;529(2):228-37. doi:http://dx.doi.org/10.1016/j.gene.2013.07.103.

55. Pajares MA, Perez-Sala D. Betaine homocysteine S-methyltransferase: just a regulator of homocysteine metabolism? Cell Mol Life Sci. 2006;63(23):2792-803.

doi:http://dx.doi.org/10.1007/3-540-37715-8_10.

56. Ragaller V, Lebzien P, Sudekum KH, Huther L, Flachowsky G. Pantothenic acid in ruminant nutrition: a review. J Anim Physiol Anim Nutr (Berl). 2011;95(1):6-16. doi:http://dx.doi.org/10.1111/j.14390396.2010.01004.x.

\section{Figures}
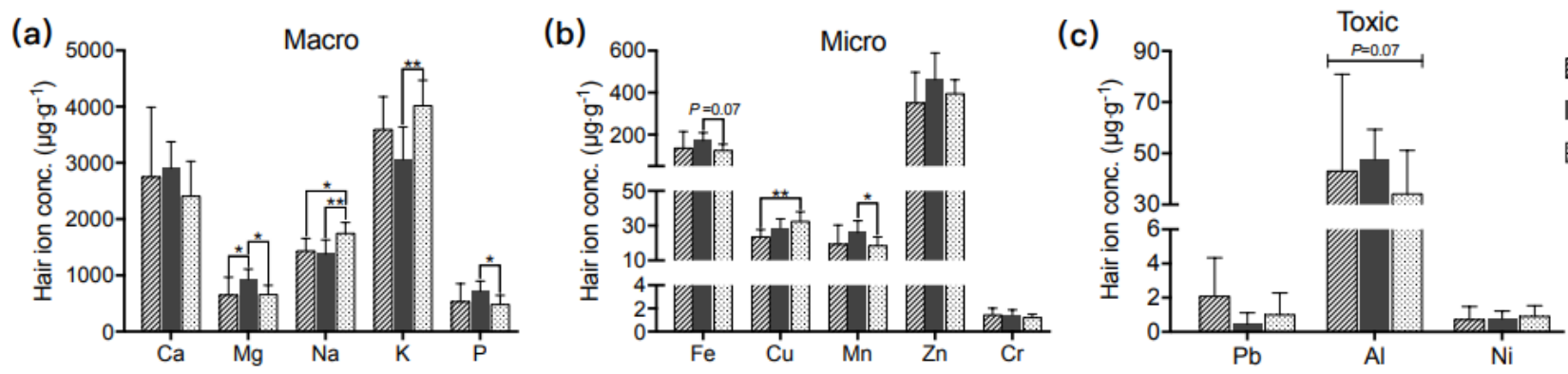

LC $\left(6 \mathrm{mg} \cdot \mathrm{kg}^{-1}\right)$

- $\operatorname{CON}\left(20 \mathrm{mg} \cdot \mathrm{kg}^{-1}\right)$

긍 $\left(300 \mathrm{mg} \cdot \mathrm{kg}^{-1}\right)$
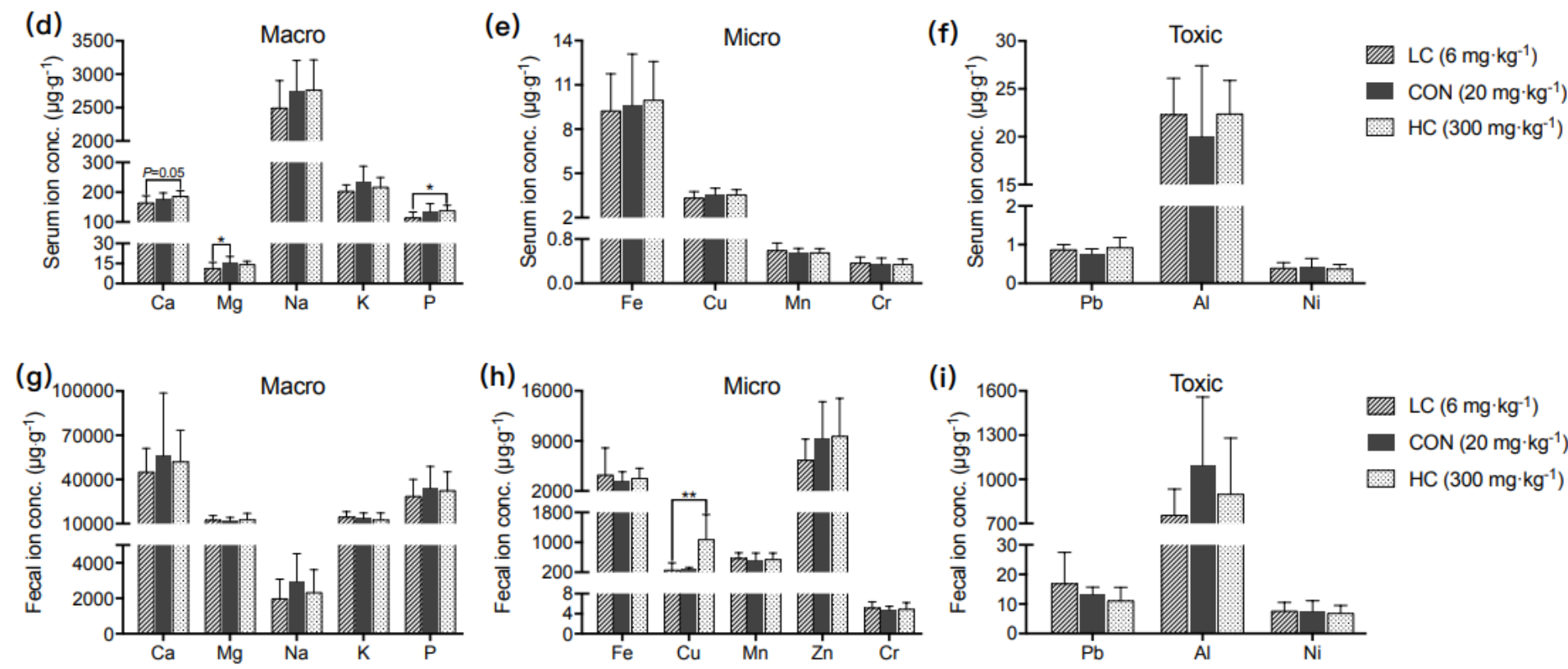

LC $\left(6 \mathrm{mg} \cdot \mathrm{kg}^{-1}\right)$

CON $\left(20 \mathrm{mg} \cdot \mathrm{kg}^{-1}\right)$

$\mathrm{HC}\left(300 \mathrm{mg} \cdot \mathrm{kg}^{-1}\right)$

Page $18 / 23$ 
Figure 1

Effect of dietary copper level on hair, serum and fecal ion concentrations in suckling piglets. Over all changes of 13 elements in hair $(a, b, c)$, serum $(d, e, f)$, and feces $(g, h, i)$ among each dietary group.

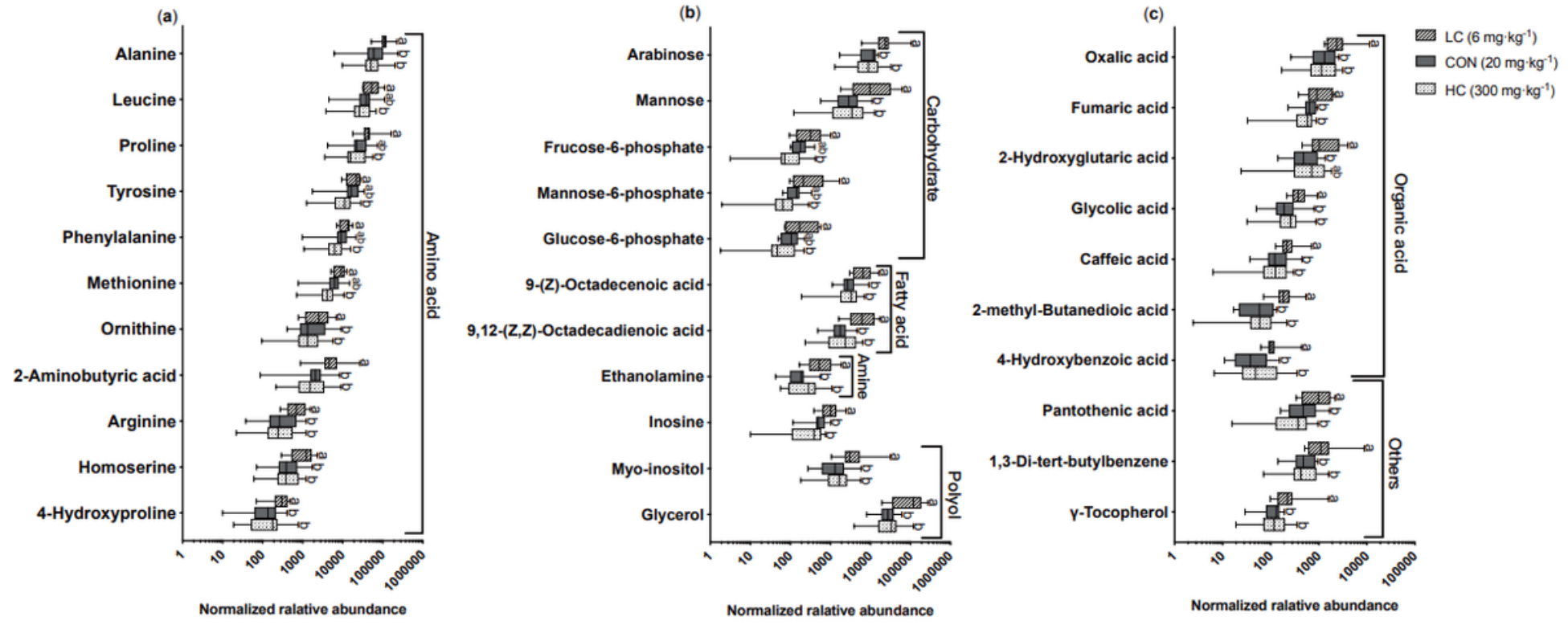

\section{Figure 2}

Effect of dietary copper level on the normalized relative abundance of fecal significant metabolites. 

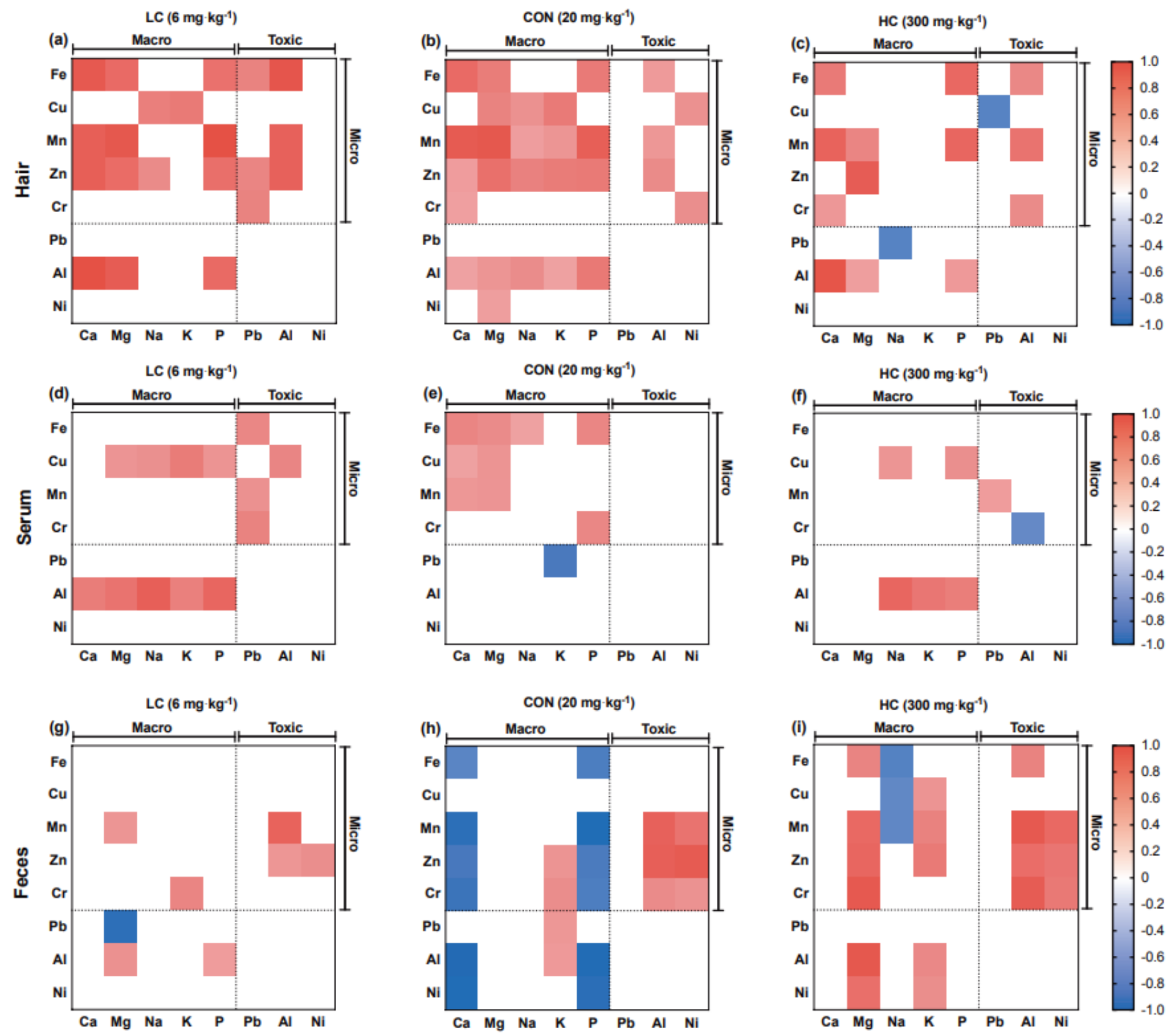

Figure 3

Changes in correlation pattern among hair, serum and fecal elements with different copper level in diet. The macro-micro, macro-toxic and micro-toxic correlation pattern were presented with different dietary copper level (6, 20 and $300 \mathrm{mg} \cdot \mathrm{kg}-1)$ in hair ( $a, b$ and $c)$, serum (d, e and f), feces ( $\mathrm{g}$, $\mathrm{h}$ and $\mathrm{i})$. The correlation which exited statistical significant were presented. The red represents a positive correlation ( $P$ $<0.05)$, the blue represents a negative correlation $(P<0.05)$, and the white shows that the correlation was not significant $(P>0.05)$. 


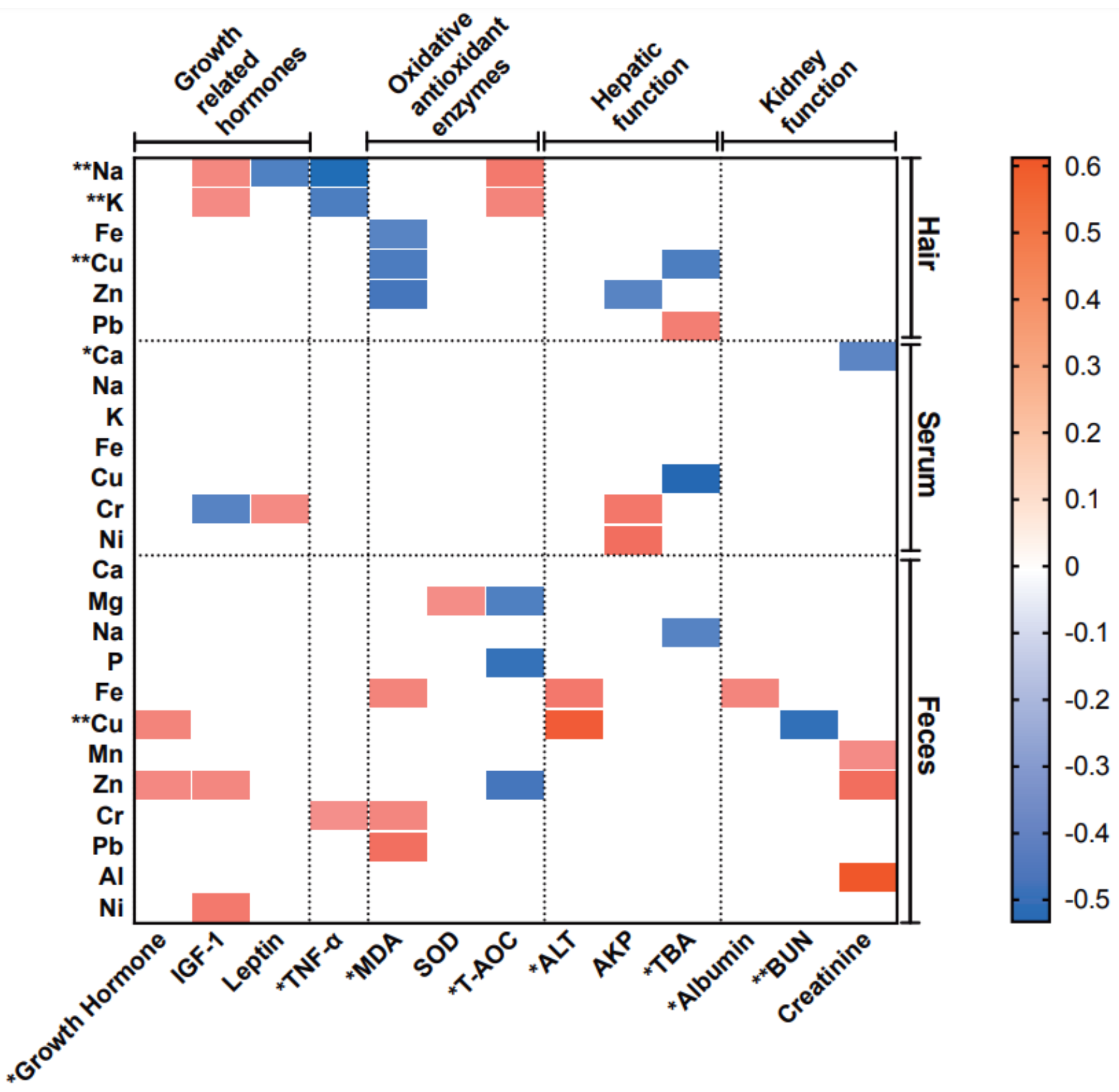

Figure 4

Correlation between ionomic profiles and serum biochemical parameters. The correlation which exited statistical significant were presented. The red represents a positive correlation $(P<0.05)$, the blue represents a negative correlation $(P<0.05)$, and the white shows that the correlation was not significant $(P>0.05)$. Significantly different among each copper group, ${ }^{*} P<0.05,{ }^{*} P<0.01$. 


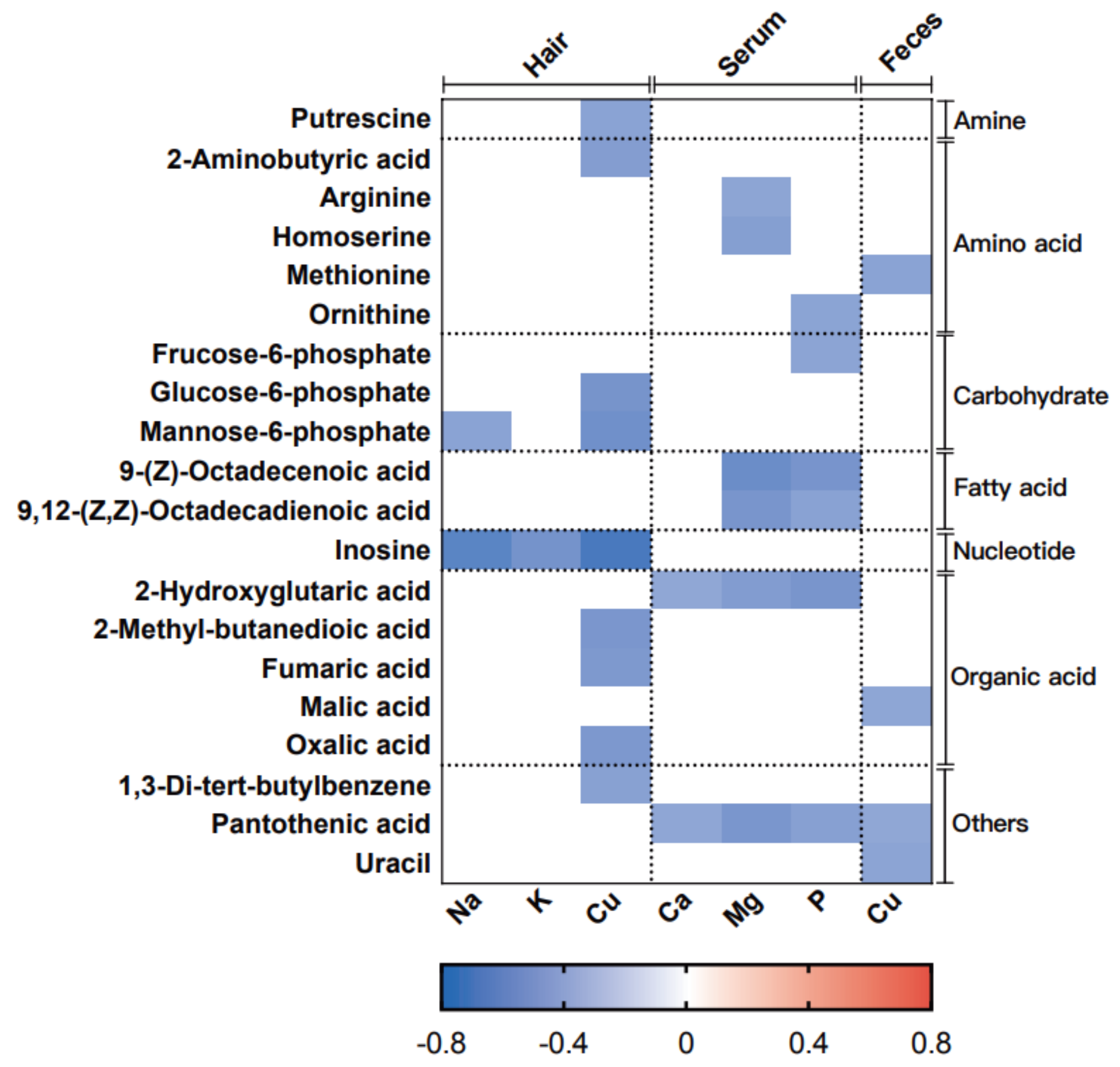

Figure 5

Correlation between ionomic profiles and fecal significant metabolites. The correlation which exited statistical significant were presented. The blue represents a negative correlation $(P<0.05)$, and the white shows that the correlation was not significant $(P>0.05)$. 


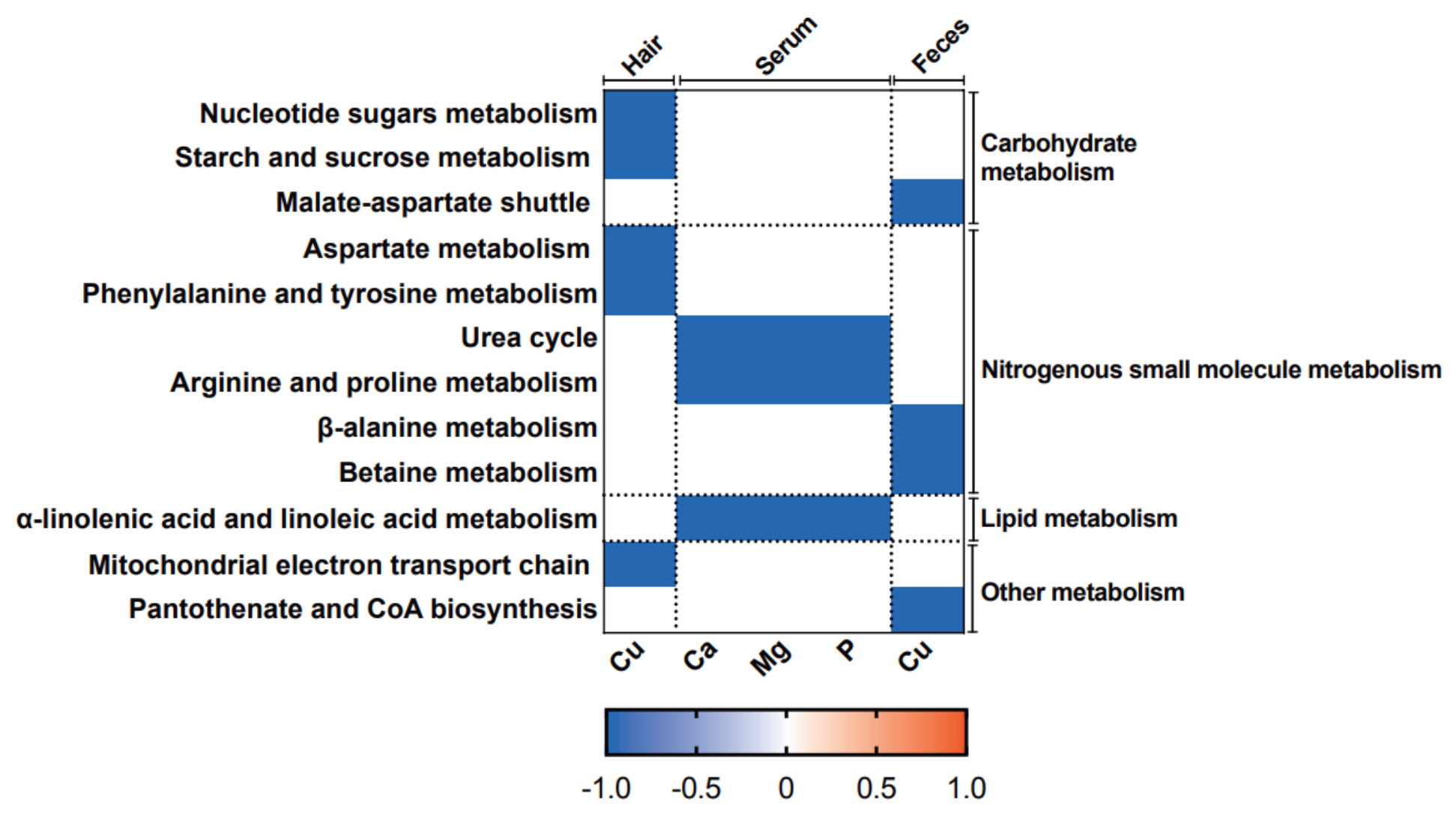

Figure 6

Correlation between ionomic profiles and metabolic pathways. The correlation which exited statistical significant were presented. The blue represents a negative correlation $(P<0.05)$, and the white shows that the correlation was not significant $(P>0.05)$.

\section{Supplementary Files}

This is a list of supplementary files associated with this preprint. Click to download.

- Additionalfile1.docx

- Additionalfile1.docx 